\title{
PERCEPTION OF ASSESSEES ON E-FILING OF TAX RETURNS
}

\author{
M. Thivya Bharathi \\ Research Scholar, Department of Corporate Secretaryship, \\ Alagappa University, Karaikudi, Tamil Nadu, India. \\ Dr. SP. Mathiraj \\ Associate Professor, Department of Corporate Secretaryship, \\ Alagappa University, Karaikudi, Tamil Nadu, India.
}

\begin{abstract}
E-filing is the great devices that are capable of distribute important social and economic benefits. The e-filing give support to government of finance and similar residents of taxpayer's liabilities of pay the tax their liabilities of successful government. This paper deals about the perception of assessees on returns of E-filling. This paper deals with the primary data collection method through questionnaire of primary data filled stabilized and analyzed to use SPSS. There are 50 respondents in this paper which be purpose and easily preferred by the individuals, government, Hindu un-divided family, firm, company, Association of Person, Body of individuals, Artificial juridical person, local authority. The study had been used to analyses of descriptive statistics, Reliability test on perception and factor analysis on satisfaction level of the respondents. The results find out even though it have provide easy to using the income tax assessees.
\end{abstract}

Key words: E-filing, Tax Returns, Perception, Satisfaction, Assessees

Cite this Article: M. Thivya Bharathi and SP. Mathiraj, Perception of Assesses on EFiling of Tax Returns, International Journal of Management, 11(12), 2020, pp 2319-2325.

http://iaeme.com/Home/issue/IJM?Volume=11\&Issue=12

\section{INTRODUCTION}

The finance of government of income tax department is the most important of country revenue in India. The income tax is first introduced to existing of 1860. But the department of ministry followed the act five years only after the new rules come to year of 1865 . These act major changes to compare the old act 1860 . These act the newly started to working thought agriculture income. On the other hand story was come the original survival the year of 1922 income tax. In the year of assessment income of last year imposing of charges showed major 
changes of ministry of finance. After the government revise the act little change of in its format of original. And the committees make little changes and income tax bill has to be submitted in Lok Sabha at the year of 1961. The President accepted the changes of income tax bill dated on $13^{\text {th }}$ September, 1961. While 1961, the act finance department of Government in India using is running the Indian taxation system.

Accordingly 2013, the finance department finance centralized system, electronic filing system of income tax assessees. The easy to file the income tax for taxpayers and at the same time reduce required for data entry at the stage end of the receipt of ITR. E-filing is the latest and useful methods of filing ITR online. Major advantage of E-filing system is saved the time, technology improvement, and rush of reduction and ease to use. After the using of efiling system through internet the public opinion is easy and useful.

\section{STATEMENT OF THE PROBLEM}

In the year 2012-13, it was experiential that $99 \%$ of tax returns were filed by hand though the evolution period of e-filing in India was 2006-07 introduced the electronic system. Uncertainty, the Income Tax is hopeful online filing of tax returns in order to digitize for all assessees' connected in order but the department still require additional efforts to enter the information from hard copies into saved the system. Taking into report the possible of e-fling which brings advantage both to the finance department, government of India and the assessees, e-file becomes significant to have majority of the assessees to file the income tax. This requires an understanding of the assessees Perception and satisfaction towards this service.

\section{OBJECTIVES OF THE STUDY}

- To study the perception of assessees on E-filing.

- To analyze the satisfaction of assessees on E-filing.

\section{REVIEW OF LITERATURE}

Naveen Kumar C, Dileep Kumar S D (2018) (Naveen Kumar C, D. K. (2018). Problems and Prospects of E-filing of Income Tax Returns. International Journal of Management Studies, $V(1(1))$, 52-61)The world introduced new technologies of day by day produced in society. And also the release new ways in all fields. At the same time the Government introduced the new system of income taxpayers through online payment it called E-filling of E-payment. When the Government introduced this facilities all assessees get same the time, cost, no tension etc., but some assessment not awareness of E-filling of E-payment.

Shares Haryani1, Bharti Motwani, and Sukhjeet Kaur Matharu (2015) (Sharda Haryanil, B. M. (2015). Behavioral Intention of Taxpayers towards Online Tax Filing in India: Journal of , 4 (1), 1-5)The paper will be deals with the taxpayers of E-filling service useful of developed the instruction of E-payment services, the most creditable of public. The more developed countries in world. The India is one of the most developed countries today. Their responsibility to the Government through where to discharge online payment of public. This paper study with the developed taxpayers perceived to the influence of factors in Government.

\section{RESEARCH METHODOLOGY}

This paper is deals with income taxpayer's perception, satisfaction towards electronic filing. The study taken from 50 respondents which includes the individuals, government, Hindu undivided family, firm, company, Association of Person, Body of individuals, Artificial juridical 
person, local authority chosen suitable and purpose. This study helps through structured questionnaire among the assessees through internet. The study using Primary data collected the method of data collection.

\section{SCOPE OF THE STUDY}

This study covers the law and rule government of income tax department of E-filing. Our scope of the study has been restricted to Perception and satisfaction of assessees.

\section{LIMITATION OF THE STUDY}

- This study taken on only 50 respondents.

- The study covers perception and satisfaction of assessees.

\section{HYPOTHESIS OF THE STUDY}

$\mathbf{H}_{1}$ : There is no relationship between gender and perception of e-filing in tax payers.

$\mathbf{H}_{2}$ : There is relationship between gender and satisfaction of e-filing in tax payers.

\section{SOCIO ECONOMIC PROFILE OF THE RESPONDENTS}

The social and economic profile of the respondents which includes Gender, Marital Status, Age, Educational Qualification, Occupation, Monthly Income and Heads of Income.

Table 1 Socio Economic Profile of the Respondents

\begin{tabular}{|c|c|c|c|}
\hline Social Factors & Classification & Frequency & Percentage (\%) \\
\hline \multirow[t]{2}{*}{ Gender } & Male & 28 & 56.0 \\
\hline & Female & 22 & 44.0 \\
\hline \multirow[t]{2}{*}{ Marital Status } & Single & 23 & 46.0 \\
\hline & Married & 27 & 54.0 \\
\hline \multirow[t]{4}{*}{ Age } & Below 30 Years & 19 & 38.0 \\
\hline & 31 to 40 & 16 & 32.0 \\
\hline & 41 to 50 & 8 & 16.0 \\
\hline & 51 to 60 & 7 & 14.0 \\
\hline \multirow{4}{*}{$\begin{array}{l}\text { Educational } \\
\text { Qualification }\end{array}$} & Illiterate & 9 & 18.0 \\
\hline & School Level & 13 & 26.0 \\
\hline & College Level & 18 & 36.0 \\
\hline & Professional & 10 & 20.0 \\
\hline \multirow[t]{4}{*}{ Occupation } & Govt Employee & 15 & 30.0 \\
\hline & Private Employee & 8 & 16.0 \\
\hline & Business & 14 & 28.0 \\
\hline & Agriculture & 13 & 26.0 \\
\hline \multirow[t]{4}{*}{ Monthly Income } & Less than 3 Lakhs & 17 & 34.0 \\
\hline & 3 to 5 Lakhs & 24 & 48.0 \\
\hline & 5 to 10 Lakhs & 1 & 2.0 \\
\hline & Above 10 Lakhs & 8 & 16.0 \\
\hline \multirow[t]{3}{*}{ Heads of Income } & Income from Salary & 23 & 46.0 \\
\hline & Profits \& gains & 14 & 28.0 \\
\hline & other sources of Income & 13 & 26.0 \\
\hline
\end{tabular}

Source: Computed Data

The table 1 indicates $56 \%$ of male respondents and $44 \%$ of female respondents. Finally, the majority of respondents are male. Followed by $46 \%$ of are unmarried and $54 \%$ are married. The high respondents are married. $38 \%$ of respondents are highly in age group of below 30 years. Therefore the young generations are aware about E-filing. $36 \%$ of respondents are majority in college level of education. Out of 50 respondents are $30 \%$ of 
government employees, $16 \%$ of Private employees, $28 \%$ of Business and $26 \%$ of agriculture. Vastly the assessees of $48 \%$ of respondents have annual income between 3 to 5 Lakhs. $46 \%$ of the respondents are Income from salary, 28\% are Profits \& gains. And the lastly, 26\% other sources of Income.

Table 2 Perception Level of Assessees on E-filing

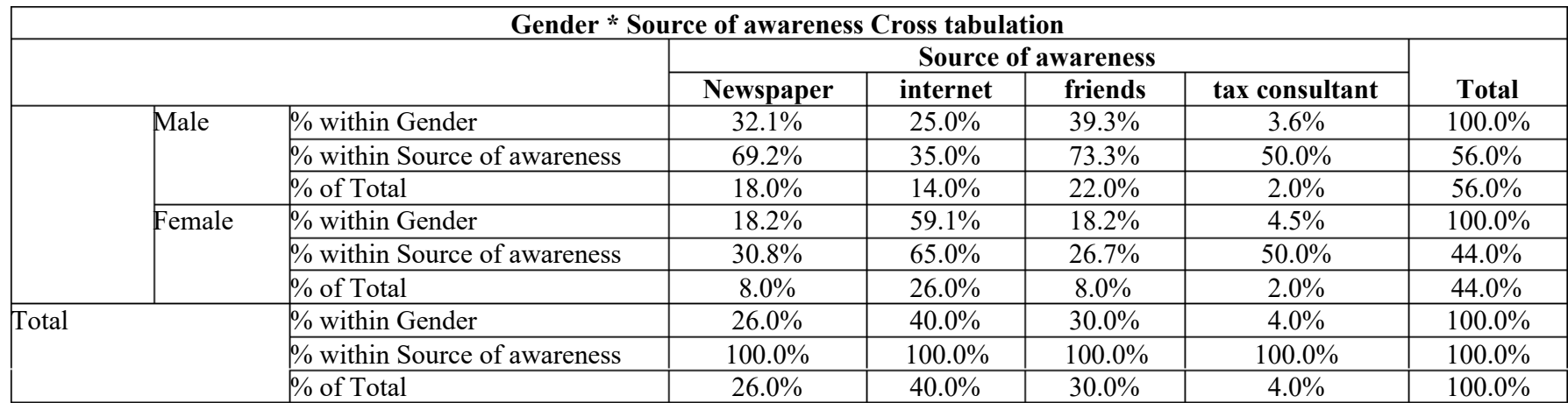

Table 3 Chi-Square

\begin{tabular}{|l|c|c|c|}
\hline & Value & df & $\begin{array}{c}\text { Asym. Sig. (2- } \\
\text { sided) }\end{array}$ \\
\hline Pearson Chi-Square & $6.361^{\mathrm{a}}$ & 3 & .095 \\
\hline Ratio of Likelihood & 6.477 & 3 & .091 \\
\hline Association of Linear-by-Linear & .046 & 1 & .830 \\
\hline N Value & 50 & & \\
\hline a. 2 cells $(25.0 \%)$ expected value $<$ 5. The expected value minimum 88. \\
\hline
\end{tabular}

Source: Computed Data

Table 3 above the table level is maximum calculated count of $X^{2}$ is 7.815 at d.f. 3 and 5\% significant level is more than the calculated value of $X^{2} 6.361$. So the null hypothesis is accepted.

Table 4 Results of Reliability in Perception of Assessees on E-filing

\begin{tabular}{|c|l|c|c|}
\hline \multicolumn{1}{|c|}{ Item-Total Statistics } \\
\hline S. No & \multicolumn{1}{|c|}{ Descriptions } & $\begin{array}{c}\text { Corrected } \\
\text { Item }\end{array}$ & $\begin{array}{c}\text { Cronbach's } \\
\text { value of Deleted }\end{array}$ \\
\hline 1 & taxation procedure is complex \& difficult & -.184 & .376 \\
\hline 2 & very complex of filing & -.012 & .336 \\
\hline 3 & The tax assessees service reduce the compliance & .197 & .274 \\
\hline 4 & The necessary of information & .005 & .331 \\
\hline 5 & The tax laws are inevitable & .079 & .309 \\
\hline 6 & The tax enforcement is necessary & -.047 & .344 \\
\hline 7 & Tax amount of high & .178 & .281 \\
\hline 8 & Deduct the tax source & .079 & .309 \\
\hline 9 & Progressive tax rate & .191 & .275 \\
\hline 10 & Before and after basic exemption & .315 & .246 \\
\hline 11 & Easy to use & .096 & .304 \\
\hline 12 & Easy to prepare & .160 & .285 \\
\hline 13 & Easy to become & .132 & .294 \\
\hline 14 & Easy to e-filing system find & .015 & .326 \\
\hline 15 & Improving performance & .253 & .257 \\
\hline 16 & Improving productivity & .204 & .275 \\
\hline 17 & Enhance effectiveness & -.040 & .346 \\
\hline 18 & Useful in preparing the filing & .111 & .300 \\
\hline 19 & Intend to use it. & -.062 & .351 \\
\hline 20 & Increase use filing & .107 & .300 \\
\hline
\end{tabular}

Source: Computed Data 
Table 5 Reliability Test

\begin{tabular}{|c|c|}
\hline Cronbach's Alpha & N of Items \\
\hline .318 & 20 \\
\hline
\end{tabular}

Cronbach's Alpha test was to check the executed by reliability test. The table shows that the numerous results acquired. The Cronbach's alpha caused in an overall score is 0.318 showing internal regularity of the items.

\section{SATISFACTION OF ASSESSEES ON E-FILING}

Table $6 \mathrm{KMO}$ and Bartlett's Test

\begin{tabular}{|l|l|l|}
\hline Kaiser-Meyer-Olkin Measure of Sampling Adequacy. & .544 \\
\hline Bartlett's Test of Sphericity & Approx. Chi-Square & 53.146 \\
\cline { 2 - 3 } & Df & 45 \\
\cline { 2 - 3 } & Sig. & .189 \\
\hline
\end{tabular}

Table 7 Eigen values Factors underlying the satisfaction of assessees on E-filing

\begin{tabular}{|c|c|c|c|c|c|c|c|c|c|}
\hline \multicolumn{10}{|c|}{ Total Variance Explained } \\
\hline \multirow[b]{2}{*}{ Component } & \multicolumn{3}{|c|}{ Initial Eigenvalues } & \multicolumn{3}{|c|}{$\begin{array}{c}\text { Extraction Sums of Squared } \\
\text { Loadings }\end{array}$} & \multicolumn{3}{|c|}{$\begin{array}{c}\text { Rotation Sums of Squared } \\
\text { Loadings }\end{array}$} \\
\hline & Total & $\begin{array}{c}\% \text { of } \\
\text { Variance }\end{array}$ & Cumulative \% & Total & $\begin{array}{c}\% \text { of } \\
\text { Variance }\end{array}$ & Cumulative \% & Total & $\begin{array}{c}\text { \% of } \\
\text { Variance }\end{array}$ & $\begin{array}{c}\text { Cumulativ } \\
\text { e \% }\end{array}$ \\
\hline 1 & 1.910 & 19.096 & 19.096 & 1.910 & 19.096 & 19.096 & 1.717 & 17.174 & 17.174 \\
\hline 2 & 1.588 & 15.884 & 34.980 & 1.588 & 15.884 & 34.980 & 1.596 & 15.963 & 33.137 \\
\hline 3 & 1.408 & 14.082 & 49.063 & 1.408 & 14.082 & 49.063 & 1.536 & 15.358 & 48.495 \\
\hline 4 & 1.266 & 12.663 & 61.726 & 1.266 & 12.663 & 61.726 & 1.323 & 13.231 & 61.726 \\
\hline 5 & .872 & 8.717 & 70.443 & & & & & & \\
\hline 6 & .787 & 7.870 & 78.313 & & & & & & \\
\hline 7 & .636 & 6.362 & 84.675 & & & & & & \\
\hline 8 & .611 & 6.109 & 90.785 & & & & & & \\
\hline 9 & .481 & 4.813 & 95.598 & & & & & & \\
\hline 10 & .440 & 4.402 & 100.000 & & & & & & \\
\hline
\end{tabular}

Source: Computed Data

Table 8 Rotated Component Matrix

\begin{tabular}{|c|c|c|c|c|}
\hline & \multicolumn{4}{|c|}{ Component } \\
\hline & 1 & 2 & 3 & 4 \\
\hline acknowledgement generated by e-filing system & .709 & & & \\
\hline e-filing procedure & .686 & & & \\
\hline availability of e-filing & .586 & & & \\
\hline e-payment procedure & & .770 & & \\
\hline facilities provided by e-filing & & .659 & & \\
\hline safety of e-filing & & & .641 & \\
\hline time limit given for e-filing & & & .573 & \\
\hline services through banks & & & & .583 \\
\hline easiness of e-filing & & & & .574 \\
\hline accuracy of e-filing & & & & .564 \\
\hline
\end{tabular}

Extraction Method: Principal Component Analysis.

a. 4 components extracted. 
Table 9

\begin{tabular}{|l|c|c|}
\hline \multicolumn{2}{|c|}{ Factor Extraction Table } \\
\hline \multicolumn{1}{|c|}{ Factors } & \% of Variance & Loading \\
\hline Procedure for E-filing & 1.981 & \\
\hline acknowledgement generated by e-filing system & & 0.709 \\
\hline e-filing procedure & & 0.686 \\
\hline availability of e-filing & 1.429 & 0.586 \\
\hline Facilities of E-filing & & \\
\hline e-payment procedure & & 0.770 \\
\hline facilities provided by e-filing & 1.241 & 0.659 \\
\hline Secure of E-filing & & 0.641 \\
\hline safety of e-filing & & 0.573 \\
\hline time limit given for e-filing & 1.721 & \\
\hline Services of E-filing & & 0.583 \\
\hline Services through banks & & 0.574 \\
\hline easiness of e-filing & & 0.564 \\
\hline accuracy of e-filing & & \\
\hline
\end{tabular}

Source: Computed Data

The table shows that the electronic filing of income tax assessees are satisfied and very useful to easy of file aware the website. The e-filing of tax returns in safety time saving and perceived risk of that feel of assessees. And also find the difficulty in network problems in last minutes of filing and the problems in remember the filing.

\section{CONCLUSIONS}

This study was expressed the income tax assessees strains of website many ecological. That means when the assessees sites to gives the procedure for e-filing of returns if changes improved. And also don't depend to others for filing the own tax payment. Govt. focuses the assessee's expectations and our problems befall of filing the returns website that helps to income tax assessees. And also focus the website server properly. The income tax returns that peak time the technology make advanced to filing of returns. The Indian government is very good work to introduced the E-filing. The assessees are so blessed and the income tax payment is advanced technology.

\section{ACKNOWLEDGEMENT}

Both the authors are thankful to the MHRD for funding RUSA 2.0 which gave an immense financial support to pursue the research work in the area of Social Science. Gracefully acknowledge the Alagappa University for providing RUSA 2.0 Ph.D fellowship which helps financially in publication.

\section{REFERENCES}

[1] Kumar, S., \& Gupta, S. (2017). A Study on Income Tax Payers Perception towards Electronic Filing. The Journal of Internet Banking and Commerce, 1-14.

[2] Chopra, M. P., Sharma, R. K., Agnihotri, A., \& Nagar, S. Attitude of Tax Payers towards EFiling of Income Tax Return: An Analytical Study.

[3] Sulaiman, A. J., Khalid, A. Z. A., \& Ibrahim, I. (2005). Perceptions of electronic filing (efiling) among tax agents in northern region of Malaysia. Faculty of Accountancy, Universiti Utara Malaysia.

[4] Puthur, J. K., Mahadevan, L., \& George, A. P. (2015). Tax payer Satisfaction and Intention to Re-use Government site for E-filing. Editorial Team Editorial Advisory Board, 46. 
[5] Adimasu, N. A., \& Daare, W. J. (2017). Tax Awareness and Perception of Tax Payers and Their Voluntary Tax Compliance Decision: Evidence from Individual Tax Payers in SNNPR, Ethiopia. International Journal of Scientific and Research Publication, 7(11), 686-695.

[6] Gayathri, P., \& Jayaumar, K. (2016). A Study on Tax Payer's Perception Towards E-Filing of Income Tax Returns with Reference to Teachers in Bengaluru East, Karnataka. Department of Commerce. Christ University. Retrieved August, 21, 2018.

[7] Chawla, C., Jain, V., Joshi, A., \& Gupta, V. (2013). A study of satisfaction level and awareness of tax-payers towards e-filing of income tax return with reference to Moradabad city. International Monthly Refereed Journal of Research in Management \& Technology, 2, 60-66.

[8] https://www.researchgate.net/publication/280216179_E-

Filing_of_Income_Tax_Awareness_and_Satisfaction_level_of_individual_Tax_payers_in_Coi mbatore_city_India.

[9] https://www.researchgate.net/publication/279251297_Behavioral_Intention_of_Taxpayers_tow ards_Online_Tax_Filing_in_India_An_Empirical_Investigation

[10] https://jas.uitm.edu.my/images/2016_DEC/2.pdf

[11] https://shodhganga.inflibnet.ac.in/jspui/bitstream/10603/245935/10/10-chapter-7.pdf

[12] https://financedocbox.com/Insurance/74619642-Problems-and-prospects-of-e-filing-of-incometax-returns.html

[13] www.ijrte.org 